DE DE GRUYTER

OPEN

DOI 10.2478/pesd-2014-0016

PESD, VOL. 8, no. 1, 2014

\title{
25 YEARS OF SUSTAINABILITY. A CRITICAL ASSESSMENT
}

\section{Alexandru-Ionuţ Petrişor ${ }^{1}$, Liliana Petrişor ${ }^{2}$}

Key words: development, economy, ecology, society, territory

\begin{abstract}
Brundtland Report' defined sustainability as a possibility to equally meet current and future needs. 15 years later, the author of the definition stated that despite of the fact that the definition does not need to be changed, its understanding bettered off during the interval. 25 years later, the present paper takes an in-depth look at the concept and its practical implications. One of the issues being addressed refers to the pillars of sustainability; their number increased by $25 \%$ to include the cultural pillar in addition to the economic, social, and cultural one. Spatial thinking added a new dimension, translating into concepts like 'sustainable communities' or 'self standing village' at the local level, and 'polycentricity' and 'cohesion' at the regional one. Furthermore, practical implications include environmental impact assessment (evolving towards strategic impact assessment), internalization of externalities, ecological restoration, and a new view on conservation, different from the one addressed by the 'Zero Growth Strategy'. In addition, the paper discusses several criticism addressed to the concept and its implementation, attempting to reveal their underlying causes. Overall, the critical analysis shows that the attempts to achieve sustainability did not change the concept as much as its understanding.
\end{abstract}

\section{Introduction}

Twenty five years had passed since WCED published the report titled "Our common future", but referred later as the Brundtland report, after its author (Brundtland, 1987). Approximately fifteen years after, Dr. Gro Harlem Brundtland stated in an interview that her definition of sustainability should not change (Bugge and Watters, 2003). However, less than five year later, summing up an international view of development strategies, Steve Bass (2007) concluded that the

1 "Ion Mincu" University of Architecture and Urbanism \& National Institute for Research and Development in Constructions, Urbanism and Sustainable Spatial Development URBAN-INCERC, alexandru_petrisor@yahoo.com;

${ }^{2}$ Architect, liliana_petrisor@yahoo.fr 
evidence indicated that development did not turn sustainable. Nevertheless, from a theoretical viewpoint, Dr. Angheluţă Vădineanu (2009) refers to a certain theory of sustainability as a stage in the evolution of systemic ecology.

Taking into account these milestones, the present research aims at seeing whether there is any progress in understanding sustainability and what is needed for its implementation. We are merely asking questions rather than answering them. Issues of interest include the pillars and dimensions of sustainability; how did they change over the last quarter of century? What are the new concepts developed in relationship to them? Other questions regard sustainability itself; did its definition change, or at least the understanding of its definition? What is actually needed to achieve sustainable development? What are the driving forces that oppose sustainability?

\section{Sustainability: the Concept}

According to what Dr. Gro Harlem Brundtland wrote, sustainability is the "development that meets the needs of the present without compromising the ability of future generations to meet their own needs" (Brundtland, 1987). According to what she said fifteen years later, the same definition is still valid today (Bugge and Watters, 2003), even though many authors attempted to redefine it; as a matter of fact, the website at http://www.reds.msh-paris.fr/communication/textes/devdur.htm collects some of the significantly different definitions proposed in the meantime. Their analysis reveals three trends; one is mathematical, suggesting the maintenance of specific indicators below or above some threshold value (Lester and Becky, 1987) or securing their monotonic growth (Beaud, 1994). The second addresses the wellbeing issue (Barbier, 1987), and the last one deals with the resilience of systems (Conway and Barbier, 1986). In addition to the author's understanding, other researchers propose different meanings of sustainability or emphasize some particular sides of it.

If the definition did not change, then what else changed? According to Dr. Gro Harlem Brundtland, the understanding of sustainability bettered off. The question is, 'What particular aspect of sustainability needs to be better understood'? The definition focuses on human needs (Norton, 1992); as a matter of fact, the first principle of Rio de Janeiro Declaration stresses out this particular aspect, stating that "human beings are at the centre of concerns for sustainable development" (United Nations, 1992c).

Dr. Gro Harlem Brundtland is underlining two issues which are now better understood; one is the nature of the pillars and dimensions of sustainability, and the other is their integration. The first issue is discussed extensively in the next chapter, and their integration in the following one. 


\section{Sustainability: Pillars and Dimensions}

Many authors consider that sustainability has three traditional pillars economic, social, and environmental (Basiago, 1999; OECD, 2004; Littig and Grießler, 2005; Gibson, 2006; Murphy, 2012). Nevertheless, other authors consider a fourth cultural one, acknowledging its potential for economic growth (Hawkes, 2001). Its recognition was the result of an intense lobby by the United Cities and Local Governments, who officially recognized it in 2010 (United Cities and Local Governments, 2010). Nevertheless, it has addressed been earlier; the Convention on Biological Conservation (United Nations, 1992b) acknowledges the role of traditional cultural practices, by recognizing "traditional knowledge, innovations and practices relevant to the conservation of biological diversity and the sustainable use of its components". Elaborated descriptions are provided by Agenda 21: these people "developed over many generations a holistic traditional scientific knowledge of their lands, natural resources and environment" (United Nations, 1992a). In a more generalizing way, the 2000 CEMAT "Guiding Principles for Sustainable Spatial Development of the European Continent" recognize "cultural heritage as a factor for development" (CEMAT, 2000). For this reason, it needs to be stressed out that the cultural pillar is considered equally important to the traditional ones, even though it has been added later (United Cities and Local Governments, 2010).

Some of the dimensions of sustainability overlap with its, economic, social, environmental, and cultural pillars. Nevertheless, a fifth dimension, of equal importance, was added to acknowledge the fact that sustainability occurs in territories of different sizes, corresponding to different administrative divisions (Bottero and Peretti, 2010; Péti, 2012). Because of its importance and relative novelty, spatial sustainability is discussed in a separate chapter.

Other dimensions are sub- or cross-sectors of the main ones; their interference is discussed in the next chapter. Examples include transportation, energy, housing, infrastructure, education, science, ethics, and management. Essentially, the guiding principle is the same, i.e. includes the ability of a system to self-sustain (autarky) after starting up by its own means, but evidence of (sustainable) growth is required in addition to it (Daly, 1990; Tofan, 1999; Curtis, 2003; Müller et al., 2011; McLellan et al., 2012).

To simply enumerate few approaches, the Club de la Budapest, founded in 1993, focused on a change of conscience and ethics (László, 2004; Ianoş et al., 2009); others looked for technological solutions (such as the ones promoted by the 1996 issue of Daedalus), considered the environmental impact of megalopolises (Dansereau and Weadock, 1970), or proposed economic, social or political issues or mixed strategies (Petrişor, 2011b). 


\section{Spatial Sustainability}

A 2008 proposed definition of spatial sustainability is "development providing for a territorial balance of satisfying at the same rate the economic, social and environmental needs of present and future generations" (Petrișor, 2009). According to Collignon (2009), its aim is to "ensure the coherence of socioeconomic objectives in relationship with the territory and its ecological and cultural functions, aiming to enhance the quality of present and future generations' life by creating sustainable communities able to manage and use resources efficiently, exploiting the innovative ecological and social potential of the economy and guaranteeing the welfare, environmental protection and social cohesion".

The spatial dimension has two important functions: (1) balances at different territorial levels cohesion and polycentricity, and (2) results into local 'sustainable communities'; at the same time, it is related to 'urban regeneration'. In the first case, territorial cohesion is defined as a "balanced distribution of human activities in a territory" (DG Regional Policy, 2004:3). The balance is reached by reducing existing gaps (for example, between urban networks), prevention of territorial imbalances (for example, between regions), through sectoral policies with spatial impact and more coherent regional policies. The active process leading to cohesion is called convergence (van Well, 2006:4). Polycentricity, a "spatial organization of cities characterized by a functional division of labor, economic and institutional integration, and political co-operation" (Nordic Centre for Spatial Development, 2003:3), is given by the morphology of a territory (number of human settlements, their hierarchy and distribution) and relationships (fluxes and cooperation) of these elements (Nordic Centre for Spatial Development, 2005:3). The second report cited distinguishes three levels of polycentricity: macro - the European alternative to the "Pentagonal", mezzo - regional, two or more cities are complementary, providing to the people and companies from the common areas access to urban functions that normally can appear only in higher ranked cities, and micro - intra-regional, complementary urban and economic functions are strengthened by the grouping of settlements (Nordic Centre for Spatial Development, 2005). Furthermore, the scale can move down to the city level, as the multiple development nuclei of a city can be seen as a form of polycentricity (McMillen and Smith, 2003).

The two concepts act together like the drivers of stability in an ecosystem: polycentricity provides for diversity, boosting the development of new centers, even of local importance, while cohesion gives coherence to the entire system, intervening when polycentricity results into serious imbalances with negative consequences; e.g., a center that develops at the expense of stopping the development of all surrounding ones (Peters, 2003; Waterhout et al., 2005; Meijers, 2008). The ecological consequence of the two is that polycentricty disperses the impacts - particularly pollution - generated by the development of 
single centers (Coffey and Shearmur, 2002; Peptenatu et al., 2011, 2012), while cohesion allows for developing coherent environmental policies for the entire territorial system.

Sustainable communities were defined by the 2005 Bristol Accord as "places where people want to live and work, now and in the future" (Office of the Deputy Prime Minister, 2006). Even though the report refers to 'communities', the eight characteristics making a community sustainable point to urban areas:

- Active, inclusive and safe: fair, tolerant and cohesive with a strong local culture and other shared community activities;

- Well run: with effective and inclusive participation, representation and leadership;

- Well connected: with good transport services and communication linking people to jobs, schools, health and other services;

- Well served: with public, private, community and voluntary services that are appropriate to people's needs and accessible to all;

- Environmentally sensitive: providing places for people to live that are considerate of the environment;

- Thriving: with a flourishing, diverse and innovative local economy;

- Well designed and built: featuring quality built and natural environment;

- Fair for everyone: including those in other communities, now and in the future (Office of the Deputy Prime Minister, 2006).

A similar concept has been developed for rural communities; the 'selfstanding village', developed by Mihail Eminescu Trust, is "an original concept promoting the sustainable development of rural communities by valorizing their unique heritage - monuments, vernacular architecture, landscape and biodiversity" (Fernolend, 2010).

New socioeconomic constraints and people needs impose to human settlements a need for change (Turok, 1992; Bassett, 1993; Loftman şi Nevin, 1995; Healey, 2004; $\mathrm{Ng}, 2005)$; under this framework, urban regeneration is the "adjustment and re-modeling process oriented to improving urban living conditions" (Petrişor, 2012b).

\section{Integrating the Pillars and Dimensions of Sustainability}

The inter-relations of the pillars and dimensions of sustainability have been widely discussed. Some scientists applied the taxonomical principles to label each possible intersection. The image displayed in Fig. 1 has been quoted and used by numerous studies, since it is distributed under the Creative Commons AttributionShare Alike 2.0 France license; it has been originally published by Jacobs and Sadler (1989). 
The particular relationship between the economic and environmental pillars, perceived through the economic perspective as two types of capitals, has been analyzed by Vădineanu (2008) based on the assumptions of classical economy (where the natural capital is used disregarding its diminishing to increase the created one), 'zero growth strategy' (stopping the development and creation of capital, and consequently the reduction of natural capital), environmental economy (understanding that the decrease of the natural capital results into a reduction of the created one too), and sustainability (implying ecological restoration, which increases the natural capital, while the integration of environmental policies in socioeconomic strategies accounts for no longer depleting the resources of the natural capital while the created one is increased).

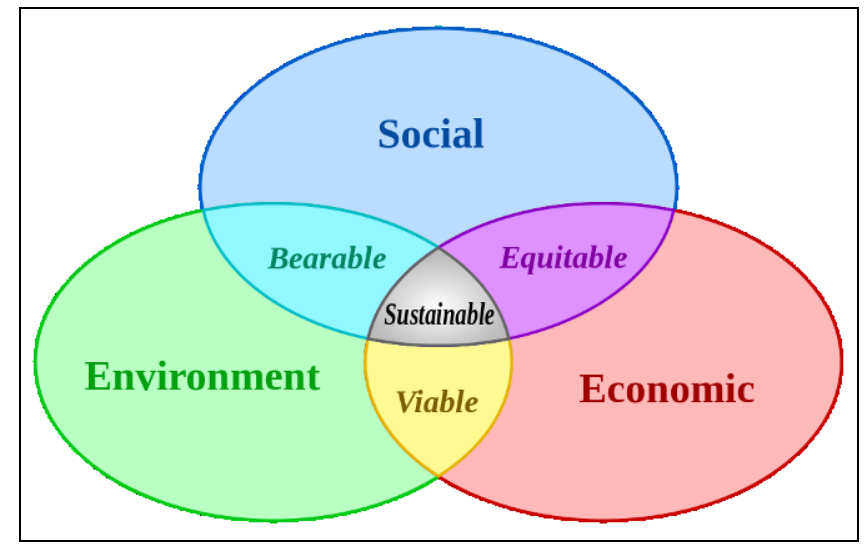

Fig. 1. Three-pillars view on sustainability. Image freely distributed under the Creative Commons Attribution-Share Alike 2.0 France license at http://en.wikipedia.org/wiki/File:Sustainable_development.svg

A similar theory is proposed by Petrişor and Sârbu (2010): the creation of capital leads to an increased complexity of territorial systems and growth of geodiversity; if natural resources are managed in an environmental-friendly manner based on a holistic managerial approach, biodiversity is "amplified" through the human contribution and geodiversity increases. An important conclusion of these findings is that sustainability implies a co-development of the natural and manmade capital, also underlined by Vădineanu (2004).

The integration is manifested and achieved through the recognition of all pillars and their equal consideration when designing the sectoral strategies of development at all administrative levels (Pope et al., 2004; Gibson, 2006; Fisher et al., 2008), as stated also in the title of the 8th chapter of Agenda 21: "integrating environment and development in decision-making" (United Nations, 1992a), and 
the integration of the policies of development for all administrative and territorial levels - international, national, regional, and local, accounting for the principles described in the previous chapter (aiming for a balance between polycentricity and cohesion). This issue is particularly important, as there is often a biased perception of sustainability addressing only or especially environmental issues (Smyth, 2011).

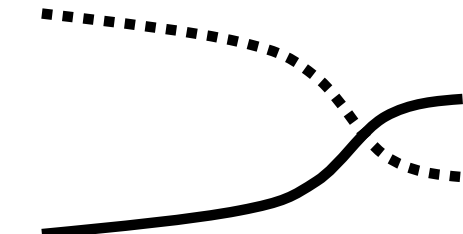

Relation between the natural capital (- - -) and the created one $(-)$ in classical economy

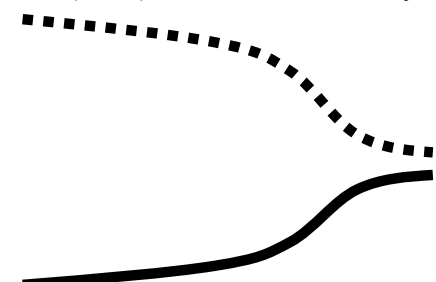

Relation between the natural capital (- - ) and the created one $(-)$ in "zero growth" theory

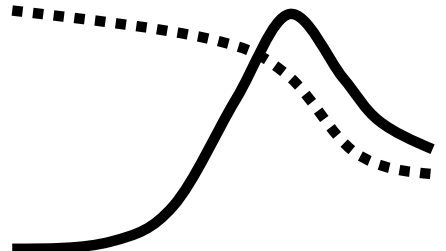

Relation between the natural capital (- - -) and the created one (-) in environmental economy

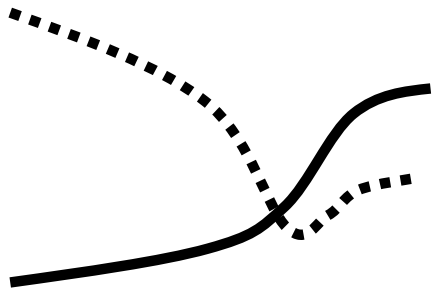

Relation between the natural capital (-- -) and the created one (-) in sustainable development, presuming ecological restoration

Fig. 2. Relationship between natural and created capital under different economic theories (Vădineanu, 2008)

\section{Basic Assumptions of Sustainability}

The theory of sustainability is based on a conceptual framework analyzing the evolution and underlying theoretical background of all implicit or explicit models of development, according to their consequences over the environment and response of the natural capital, presented in Table 1. Sustainability relies on a holistic and systemic understanding of the environment as a hierarchy of functional structures, regardless of their natural or socioeconomic nature, replacing the anthropocentric one (Vădineanu, 1998; Ungureanu et al., 2011). Ecological systems are the support of life and constitute the ecological foundation (Pawlowski and Auslander, 2000; Vădineanu, 2007; Haberl et al., 2009).

This theory is based on understanding the environment, from a transdisciplinary perspective, as a sum of capitals; the first one is the natural capital, represented by the natural, life-supporting systems, constituting the ecological 
foundation, and composed of environmental goods and services, and the second, representing the anthropic environment or anthroposphere (Vădineanu, 1998), has three components: (1) the economic capital, composed by built infrastructure (physical capital), the technosphere (technological environment), (2) the social capital, consisting of institutional/administrative capital, and of all relations among humans, regulated (by juridical and socio-economic constraints) or not, and (3) the cultural capital, consisting of a traditional set of perceptions and practices, and human knowledge and abilities (Vădineanu, 1998; Petrişor, 2011b).

Tab. 1. A timeline of the relationships between human society and natural systems

\begin{tabular}{|c|c|c|c|c|}
\hline Moment & $\begin{array}{l}\text { Early } \\
\text { history }\end{array}$ & $\begin{array}{l}\text { Industrial } \\
\text { revolution }\end{array}$ & $\begin{array}{c}\text { Oil Crisis, Club of } \\
\text { Rome (1970's) }\end{array}$ & $\begin{array}{c}\text { Brundtland Report, } \\
\text { 1988; Rio de Janeiro, } \\
1992\end{array}$ \\
\hline Model & No model & No model & $\begin{array}{l}\text { "Zero growth" } \\
\text { strategy }\end{array}$ & $\begin{array}{l}\text { Sustainable } \\
\text { development }\end{array}$ \\
\hline Action & $\begin{array}{l}\text { Life in } \\
\text { harmony } \\
\text { with } \\
\text { nature }\end{array}$ & $\begin{array}{l}\text { Degradation of the } \\
\text { natural capital }\end{array}$ & $\begin{array}{l}\text { Strict conservation } \\
\text { (preservation) of } \\
\text { biodiversity }\end{array}$ & $\begin{array}{l}\text { Conservation, impact } \\
\text { assessment, } \\
\text { ecological restoration, } \\
\text { internalization of } \\
\text { externalities }\end{array}$ \\
\hline $\begin{array}{l}\text { Consequence / } \\
\text { reaction of } \\
\text { environment } \\
\end{array}$ & $\begin{array}{l}\text { Low } \\
\text { impact }\end{array}$ & $\begin{array}{l}\text { Reduction of } \\
\text { environmental } \\
\text { goods \& services }\end{array}$ & $\begin{array}{l}\text { Development } \\
\text { would stop }\end{array}$ & $\begin{array}{l}\text { Co-development of } \\
\text { natural systems \& } \\
\text { human society }\end{array}$ \\
\hline $\begin{array}{c}\text { Ecological } \\
\text { approach }\end{array}$ & None & Anthropocentric & Anthropocentric & Holistic \\
\hline
\end{tabular}

It is obvious that the main barrier that sustainability must pass is the competition between the natural and anthropic capital (Mazilu and Giurgea, 2011). On the one hand, man-dominated systems are strictly dependent on goods and services provided by the natural ones (Sârbu, 1999, 2006), but they are also competing for space (Peptenatu et al., 2011, 2012; Petrişor, 2012a). The drivers of environmental change are political (Peptenatu et al., 2010), social and economic (Petrişor et al., 2010). More important than the drivers themselves is their interaction, due to synergistic effects. The term "global change" was introduced to encompass all man-generated impacts affecting the ecosphere: land use changes, climate change, and energy use (Dale et al., 2011).

Another important point that needs to be stressed out here, even though it will be discussed in the next chapter, is that the principles of sustainability do not apply only to concrete and ongoing activities, but also to plans, projects, programs, and to support activities, such as management, legislation etc. (Owens, 1994; Judge and 
Douglas, 1998); this is, in fact, an illustration of the international precautionary principle of environmental law (Trouwborst, 2009).

Last but not least, scale is a crucial issue in sustainability. It has been shown above that the key to sustainability is integration, which needs to be manifested, from a spatial perspective, at all administrative and territorial levels. More exactly, according to Dr. Angheluţă Vădineanu $(2004,2007,2009)$ and Dr. Radu Ştefan Vădineanu (2008), the key to sustainability is balancing socio-ecological complexes at all hierarchical levels.

\section{Practical Implications of Sustainability}

Previous discussions have attempted to analyze the theoretical framework of sustainability, addressing issue related to what needs to be known and what the appropriate approaches to achieving a sustainable development are. In the next paragraphs, the discussion focuses on the concrete means to turn development sustainable in practice.

Essentially, there are three issues needed to account for; (1) ecological restoration, (2) environmental impact aimed at internalizing externalities (accounting for the "polluter pays" principle) and avoiding further degradation (the precautionary principle, mentioned in the previous section), and (3) conservation of biodiversity.

With respect to the first one, sustainability must account for the mistakes made in the past through the ecological restoration of degraded systems, in order to offer future generations an unaltered part of today's natural capital; the ecological engineering techniques are an important instrument. This goal is connected to the third one, as safeguarding for the future generation an unaltered part of present environment requires bringing it to almost pristine conditions (Aronson et al., 2006; Choi et al., 2008).

Sustainability must look at all present activities and assess their impact (economic, social, environmental, and cultural) from a triple perspective: (1) ensure that all activities are designed for a long term; (2) assess the consumption of resources and generation of waste or pollution in order to hold the polluter responsible and prevent further degradation (Clive, 1999); and (3) provide mechanisms for the internalization of externalities (Pretty et al., 2001), putting into practice the "polluter pays" principle. At the same time, benefits must be returned to those who give up over some benefits in order to help the future generations (such as the indigenous communities or companies likely to adopt an environmentally-friendly behavior etc.). Based on these principles, the new integrated approach, called Strategic Environmental Assessment, tends to replace the Environmental Impact Assessment. The main difference between the two is that 
"the object of assessment generates different methodological requirements related to the scale of assessment and to the decision-making process" (Partidário, 2007). The new approach integrates better the pillars of sustainability (Abaza et al., 2004) and is particularly useful to solve specific issues of transition countries, such as the consequences of industrialization (Alshuwaikhat, 2005).

Finally, sustainability must safeguard for the future generations an important part of today's biodiversity, through the declaration of natural protected areas (Hoag and Skold, 1996; Holling, 2000). The design of such areas must take into account several principles: (1) conservation must not be understood as strict preservation, in an unaltered state, but as maintenance of systems within the carrying capacity limits, ensuring the structural and functional integrity of lifesupporting systems, (2) conservation must reflect the international, national, regional, and local representativeness of chosen areas for the biogeographical space, ecological zoning, or spatial other form of diversity, (3) conservation implies an active management, requiring the existence of a plan and a structure responsible for its implementation, (4) within the protected areas, zoning must allow for a differentiated management; the core areas must be buffered gradually, ensuring the transition of practices to "no restriction" regions such that the core areas are not affected; (5) local populations must be attracted in drafting the plan of management, ensuring their support for its implementation, including a correct redistribution of benefits, and (6) multi-sectoral, regional, national, and international cooperation is very important for making all protected areas working together as a global network (Petrişor, 2011a).

\section{Criticisms addressed to Sustainability}

While it seemed that sustainability could solve all environmental issues, many authors started criticizing it. Criticisms ranged gradually from addressing the inability of putting it into practice to dealing with its means and finally denying its very essence; on a gradual scale, Steve Bass (2007), researcher at the International Institute for the Environment and Development and former advisor on environmental issues to the UK Department of International Development, showed that "three UN-commissioned reports from 2005 show clearly that development has not yet become sustainable". Serge Latouche (1994) criticized the means stating that "sustainable development is like the road to hell, paved with good intentions". Finally, Nicholas Georgescu-Roegen (1991:53) addressed the core saying that "there is not the slightest doubt that sustainable development is one of the most destructive concepts".

Analyzing the nature of criticisms, Sneddon et al. (2006) mention fundamental contradictions between the economic growth in developing countries 
and conservation, and the omission of power relations among the local-to-global actors and institutions supporting unsustainable development. Smyth (2011) resumes criticisms concerning the institutionalization of sustainability, as well as its programmatic implementation resulting into a precedence of the interests of donors over those of recipient communities.

\section{Conclusions}

This research attempted to summarize the changes occurred during a quarter of century since the concept of sustainability was defined. The analysis was focused on theoretical and practical issues. The results revealed that the definition did not change, but its understanding was enriched substantially. The number of pillars increased by $25 \%$ and many dimensions were addressed; for each of them theories were elaborated, turning sustainability into a science. However, little progress was made with respect to its practical implementation, resulting into numerous criticisms, addressing its means and even its core. Even though humanity seems to understand better what needs to be done for achieving sustainability, these requirements seem to be hard to put into practice. It can be only hoped for the concept to become operational in a degree commensurate with its improved understanding.

\section{References}

Abaza H., Bisset R., Sadler B. (2004), Environmental Impact Assessment and Strategic Environmental Assessment: Towards an Integrated Approach, United Nations Environment Program, Geneva, Switzerland.

Alshuwaikhat H. A. (2005), Strategic environmental assessment can help solve environmental impact assessment failures in developing countries, Environmental Impact Assessment Review 25(4):307-317.

Aronson J., Clewell A. F., Blignaut J. N., Milton Sue J. (2006), Ecological restoration: A new frontier for nature conservation and economics, Journal for Nature Conservation 14(3-4):135-139.

Barbier E. B. (1987), The Concept of Sustainable Economic Development, Environmental Conservation 14(2):101-110.

Beaud M. (1994), Face à la croissance mortifère, quel développement durable? Tiers Monde 35:137-143.

Bass S. (2007), A New Era in Sustainable Development. An IIED Briefing, International Institute for Environment and Development, London, UK.

Bassett K. (1993), Urban cultural strategies and urban regeneration: a case study and critique, Environment and Planning A 25(12):1773-1788.

Basiago A. D. (1999), Economic, social, and environmental sustainability in development theory and urban planning practice, The Environmentalist 19:145-161. 
Bottero Marta, Ferretti Valentina, (2010), Integrating the analytic network process (ANP) and the driving force-pressure-state-impact-responses (DPSIR) model for the sustainability assessment of territorial transformations, Management of Environmental Quality: An International Journal 21(5):618-644.

Brundtland Gro Harlem (1987), Our Common Future, WCED, Oxford University Press, Oxford.

Bugge H. C., Watters L. (2003), A Perspective on Sustainable Development after Johannesburg on the Fifteenth Anniversary of Our Common Future: An Interview with Gro Harlem Brundtland, Georgetown International Environmental Law Review 15:359-366.

CEMAT - European Conference of Ministers responsible for Regional Planning (2000), Guiding Principles for Sustainable Spatial Development of the European Continent adopted at the 12th Session of the European Conference of Ministers responsible for Regional Planning on 7-8 September 2000 in Hanover, document CEMAT(2000)7.

Choi Y. D., Temperton Vicky M., Grootjans A. P., Halassy Melinda, Hobbs R. J., Naeth M. Anne, Torok K. (2008), Ecological restoration for future sustainability in a changing environment, Ecoscience 15(1):53-64.

Clive G. (1999), Testing for sustainable development through environmental assessment, Environmental Impact Assessment Review 19(2):175-200.

Coffey W. J., Shearmur R. G. (2002), Agglomeration and Dispersion of High-order Service Employment in the Montreal Metropolitan Region, 1981-96, Urban Studies 39(3):359-378.

Colignon P. (2009), Situation et défis du monde rural - Le patrimoine et le paysage au cour des enjeux du développement territorial durable, Aménagement du territoire européen et paysage 88:99-103.

Conway G. R., Barbier E. B. (1986), After the Green Revolution: Sustainable and Equitable Agriculture Development, Futures 20:651-678.

Curtis F. (2003), Eco-localism and sustainability, Ecological Economics 46(1):83-102.

Dale V. H., Efroymnson R. A., Kline K. L. (2011), The land use - climate change energy nexus, Landscape Ecology 26:755-773.

Daly H. E. (1990), Toward some operational principles of sustainable development, Ecological Economics 2(1):1-6.

DG Regional Policy (2004), Third Interim Territorial Cohesion Report (Preliminary results of ESPON and EU Commission studies), Office for Official Publications of the European Communities, Luxemburg.

Fernolend Caroline (2010), 10 years experience of Mihai Eminescu Trust foundation in revitalizing Transylvanian villages - a commitment for valorizing the Romanian cultural heritage, National Conference Urban Concept, Sinaia, March 12, 2010.

Fisher B., Turner K., Zylstra M., Brouwer R., de Groot R., Farber S., Ferraro P., Green R., Hadley D., Harlow J., Jefferiss P., Kirkby C., Morling P., Mowatt S., Naidoo R., Paavola J., Strassburg B., Yu D., Balmford A. (2008), Ecosystem services and economic theory: integration for policy-relevant research, Ecological Applications 18:2050-2067. 
Georgescu-Roegen N. (1991), Correspondence with J. Berry, in: Bonaïuti M, (Ed.) La teoria bioeconomica. La "nuova economia" di Nicholas Georgescu Roegen, Carocci, Rome, Italy.

Gibson R. B. (2006), Beyond the pillars: sustainability assessment as a framework for effective integration of social, economic and ecological considerations in significant decision-making, Journal of Environmental Assessment Policy and Management 8(3):259-280.

Haberl H., Gaube Veronika, Díaz-Delgado R., Krauze Kinga, Neuner Angelika, Peterseil J., Singh S. J., Vădineanu A. (2009), Towards an integrated model of socioeconomic biodiversity drivers, pressures and impacts. A feasibility study based on three European long-term socio-ecological research platforms, Ecological Economics 68(6):1797-1812.

Hawkes J. (2001), The fourth pillar of sustainability: Culture's essential role in public planning, Melbourne, Australia.

Healey Patsy (2004), Creativity and urban governance, Policy Studies 25(2):87-102.

Hoag Dana L., Skold M. D. (1996), The relationship between conservation and sustainability, Journal of Soil and Water Conservation 51:4292-4295.

Holling C. S. (2000), Theories for sustainable futures, Conservation Ecology 4(2):7.

Ianoş I., Peptenatu D., Zamfir D. (2009), Respect for environment and sustainable development, Carpathian Journal of Earth and Environmental Sciences 4(1):81-93.

Jacobs P., Sadler B. (Eds.) (1989), Sustainable Development and Environmental Assessment: Perspectives on Planning for a Common Future, Canadian Environmental Assessment Research Council, Ottawa.

Judge W. Q., Douglas T. J. (1998), Performance Implications of Incorporating Natural Environmental Issues into the Strategic Planning Process: An Empirical Assessment, Journal of Management Studies 35(2):241-262.

Latouche S. (1994), Développement durable: un concept alibi. Main invisible et main mise sur la nature, Tiers Monde 137:80.

Lester B., Becky J. (1987), Global Sustainability: toward definition, Environmental management 11(6):713-719.

Littig B., Grießler E. (2005), Social sustainability: a catchword between political pragmatism and social theory, International Journal of Sustainable Development 8(12):65-79.

Loftman P., Nevin B. (1995): Prestige Projects and Urban Regeneration in the 1980s and 1990s: a review of benefits and limitations, Planning Practice \& Research 10(34):299-316.

Mazilu Mirela, Giurgea Doina (2011), Contradictions between the human development and the necessity of implementing the sustainable development principles, Present Environment and Sustainable Development 5(2):241-253.

McLellan B., Zhang Q., Farzaneh H., Utama N. A., Ishihara K. N. (2012), Resilience, Sustainability and Risk Management: A Focus on Energy, Challenges 3:153-182.

McMillen D. P., Smith S. C. (2003), The number of subcenters in large urban areas, Journal of Urban Economics 53(3):321-338. 
Meijers E. (2008), Measuring Polycentricity and its Promises, European Planning Studies 16(9):1313-1323.

Murphy K. (2012), The social pillar of sustainable development: a literature review and framework for policy analysis, Sustainability: Science, Practice, \& Policy 8(1):15-29.

Müller M. O., Stämpfli A., Dold Ursula, Hammer T. (2011), Energy autarky: A conceptual framework for sustainable regional development, Energy Policy 39(10:5800-5810.

Ng M. K. (2005), Quality of Life Perceptions and Directions for Urban Regeneration in Hong Kong, Social Indicators Research 71(1-3):441-465.

Nordic Centre for Spatial Development (2003), ESPON 1.1.1. Third interim report. The role, specific situation and potentials of urban areas as nodes in a polycentric development, NORDREGIO, Sweden.

Nordic Centre for Spatial Development (2005), ESPON 1.1.1. Potentials for polycentric development. Final Report, NORDREGIO, Sweden.

Norton B. (1992), Sustainability, Human Welfare, and Ecosystem Health, Environmental Values 1(2):97-111.

OECD (2004), Measuring sustainable development. Integrated economic, environmental and social frameworks, OECD, Paris, France.

Office of the Deputy Prime Minister (2006), A common approach to creating sustainable communities: "The Bristol Accord", in: UK Presidency. EU Ministerial Informal on Sustainable Communities. Policy Papers, ODPM Publications, London, Document 05 EUPMI 03656/A

Owens Susan (1994), Land, Limits and Sustainability: A Conceptual Framework and Some Dilemmas for the Planning System, Transactions of the Institute of British Geographers 19(4):439-456.

Partidário M. d. R. (2007), Strategic Environmental Assessment. Good Practices Guide. Methodological Guidance, Portuguese Environment Agency, Amadora, Portugal.

Pawlowski C. W., Auslander D. M. (2000), A hierarchical approach to the sustainable management of controlled ecological life support systems, Life support \& biosphere science 7(2):171-185.

Peptenatu D., Merciu Cristina, Merciu G., Drăghici C., Cercleux Loreta (2012), Specific features of environment risk management in emerging territorial structures, Carpathian Journal of Earth and Environmental Sciences 7(2):135-143.

Peptenatu D., Pintilii R. D., Drăghici C., Stoian Daniela (2010), Environmental pollution in functionally restructured urban areas: case study - the city of Bucharest, Iranian Journal of Environmental Health Sciences and Engineering 7(1):87-96.

Peptenatu D., Pintilii R. D., Drăghici C. (2011), Environmental risk management of urban growth poles regarding national importance, International Journal of Environmental Science \& Technology 8(4):737-746.

Peters D. (2003), Cohesion, Polycentricity, Missing Links and Bottlenecks: Conflicting Spatial Storylines for Pan-European Transport Investments, European Planning Studies 11(3):317-339.

Petrişor A.-I. (2008), Towards a definition of sustainable development [in Romanian], Amenajarea Teritoriului şi Urbanismul 7(3-4):1-5. 
Petrişor AI (2011a), Spatial principles of conserving biodiversity through natural protected areas [in Romanian], Analele Arhitecturii 6(1):37-39.

Petrişor A.-I. (2011b), Systemic theory applied to ecology, geography and spatial planning. Theoretical and methodological developments, Lambert Academic Publishing, Saarbrücken, Germany.

Petrişor A.-I. (2012a), Land cover and land use analysis of urban growth in Romania, Human Geographies 6(1):47-51.

Petrişor A.-I. (2012b), Redefining urban regeneration, Argument 4:201-215.

Petrişor A.-I., Ianoş I., Tălângă C. (2010), Land cover and use changes focused on the urbanization processes in Romania, Environmental Engineering and Management Journal 9(6):765-771.

Petrişor A.-I., Sârbu C. N. (2010), Dynamics of geodiversity and eco-diversity in territorial systems, Journal of Urban and Regional Analysis 2(1):61-70.

Péti M. (2012), A territorial understanding of sustainability in public development, Environmental Impact Assessment Review 32(1):61-73.

Pope Jenny, Annandale D., Morrison-Saunders A. (2004), Conceptualising sustainability assessment, Environmental Impact Assessment Review 24(6):595-616.

Pretty J., Brett C., Gee D., Hine Rachel, Mason C., Morison J., Raymenti M., van der Bij G., Dobbs T. (2001), Policy Challenges and Priorities for Internalizing the Externalities of Modern Agriculture, Journal of Environmental Planning and Management 44(2):263-283.

Sârbu C. N. (1999), Urban rehabilitation and development - a main dimension of socioeconomic transition. A model of approach: the urban texture [in Romanian], in: Vădineanu A., Sustainable development, Vol. 2, Mechanisms and instruments, University of Bucharest Press, Bucharest, pp. 298-329.

Sârbu C. N. (2006), Housing in Romania: a framework approach [in Romanian], "Ion Mincu" University Press, Bucharest.

Smyth L. (2011), Anthropological Critiques of Sustainable Development, Cross-Sections 7:78-85.

Sneddon C., Howarth R. B., Norgaard R. B. (2006), Sustainable development in a postBrundtland world, Ecological Economics 57:253-268.

Tofan A. (2009), Economic requirements for Romania's sustainable development, Present Environment and Sustainable Development 3:113-123.

Turok I. (1992), Property-led urban regeneration: panacea or placebo?, Environment and Planning A 24(3):361-379.

Trouwborst A. (2009), Prevention, precaution, logic and law. The relationship between the precautionary principle and the preventative principle in international law and associated questions, Erasmus Law Review 2(2):105-127.

Ungureanu Irina, Bănică A., Tudora D., Ursu A., Sfîcă L. (2011), The urban environment and the sustainable development. Conceptual and applicative preliminaries, Present Environment and Sustainable Development 5(2):111-122.

United Cities and Local Governments (2010), Culture: Fourth Pillar of Sustainable Development. Policy statement, United Cities and Local Governments, Barcelona, Spain. 
United Nations (1992a), Agenda 21, United Nations Conference on Environment \& Development, Rio de Janeiro, Brazil.

United Nations (1992b), Convention on biological diversity, Rio de Janeiro, Brazil,

United Nations (1992c), Rio Declaration on Environment and Development, in: UN Conference on Education and Development, Agenda 21: Programme of Action for Sustainable Development 7, UN Sales No E.93.I.11, UN Doc. A/CONF.151/26/Rev1

van Well L (2006), ESPON project 1.1.3. Enlargement of the European Union and the wider European Perspective as regards its Polycentric Spatial Structure, The Royal Institute of Technology, Stockholm, Sweden.

Vădineanu A. (1998), Sustainable development. Vol. I. Theoretical foundations of sustainable development [in Romanian], University of Bucharest Press, Bucharest.

Vădineanu A. (2004), Management of development. An ecosystemic approach [in Romanian], Ars Docendi Press, Bucharest.

Vădineanu A. (2007), The ecosystem approach applied to the management of the coastal socio-ecological systems, in: Gonenc I. E., Koutitonsky V. G., Brenda Rashleigh, Ambrose Jr. R. B., Wolflin J. P. (Eds.), Assessment of the Fate and Effects of Toxic Agents on Water Resources, Springer, Amsterdam, pp. 199-224.

Vădineanu A. (2009), Key conditions necessary for organizing and promoting inter- and trans-disciplinary researches on the complexity of nature, environment and society, doctoral summer school on the complexity of nature, environment and human society, Bucharest.

Vădineanu R.-Ş. (2008), Methods and indicators for assessing the natural capital and sustainability of socio-economic systems [in Romanian], Doctoral Dissertation, University of Bucharest, Bucharest.

Waterhout B., Zonneveld W. A. M., Meijers E. J. (2005), Polycentric Development Policies in Europe: Overview and Debate, Built Environment 31(2):163-173. 